\section{Spennende, men noe fragmentarisk om psykosomatikk}

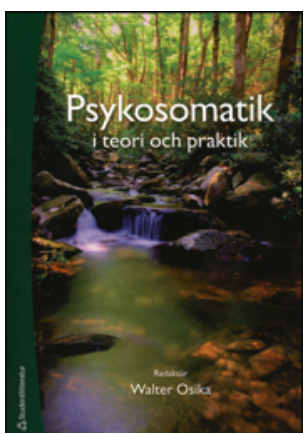

Walter Osika, red.

Psykosomatik i teori och praktik

358 s, ill. Lund: Studentlitteratur, 2013

Pris SEK 351

ISBN 978-91-44-06981-4

Redaktør er Walter Osika, som er spesialist i indremedsin, kardiologi og psykiatri ved Karolinska Institutet. Det er i alt 20 forfattere, og bortsett fra professor McEwen er alle svenske. De fleste er leger.

Målgruppen er studenter i medisin, sykepleie, jordmorfag, psykologi, fysioterapi og ergoterapi, i tillegg til andre kliniske terapeuter. De første seks kapitlene er en introduksjon med teoretiske og konseptuelle betraktninger, historikk, migrasjon og kulturelle aspekter ved psykosomatikk, sosiale roller, arbeidsmiljø og kritiske livshendelser som risiko for psykosomatiske plager. Deretter kommer ett kapittel med et allmennmedsinsk perspektiv på psykosomatisk medisin. Hoveddelen består av flere kapitler som har organspesifikt søkelys.

Forfatterne vil mye, og mye er bra. For denne anmelder er det likevel et problem at selve begrepet «psykosomatik» er uklart og dårlig operasjonalisert, både i boken og generelt. Det er bare avsatt en halv side til begrepsdiskusjon.

Det er positivt at arbeidsmiljø og kritiske livshendelser trekkes frem som risiko for psykosomatiske lidelser. Den teoretiske delen har interessante ansatser, virker utradisjonell og alternativ, men fremstår dessverre som ganske fragmentert.

I den organspesifikke delen er tilstandene godt beskrevet i forhold til psykosomatikk/funksjonelle somatiske syndromer, sykdommer og nevrobiologi. Bortsett fra kapitlet om hjerte- og karsykdommer er det god bruk av kliniske eksempler i denne delen, noe som gjør den interessant og nyttig å lese. Kapitlene om smerte og stress, som kommer etter de organspesifikke lidelsene, mangler derimot kliniske kasuistikker, mens kapitlet om søvnproblemer er bra på det.

Den siste delen dreier seg om behandling, men ikke gjengitt som en systematisk oversikt med evidensbasert kunnskap eller «state of the art». I stedet presenteres alternative behandlinger med oppmerksomt nærvær (mindfulness), kunstterapi, naturterapi og komplementær og alternativ medisin (KAM).

Dette er en spennende, men noe fragmentarisk og konseptuelt uklar bok som omhandler vanskelige og viktige problemstillinger. Den er mer teoretisk enn praktisk, ikke evidensbasert, men vil kunne være nyttig for målgruppen, så fremt man supplerer med andre bøker som utfyller dette vanskelige feltet.

Egil Andreas Fors

Overlege, St. Olavs Hospital

Trondheim

\section{Glimrende om gruppeanalytisk psykoterapi}

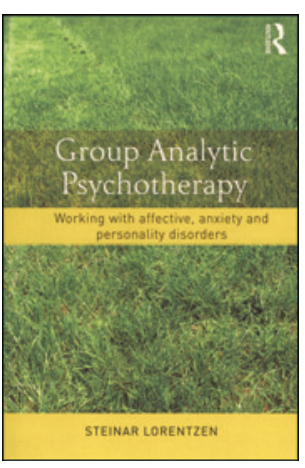

Steinar Lorentzen Group analytic psychotherapy

Working with affective, anxiety and personality disorders. 96 s, tab. Hove: Routledge, 2013 Pris GBP 23

ISBN 978-0-415-83149-9

Gruppebehandling av psykiatriske pasienter var ganske vanlig i Norge fra 1960-årene, men det var først i perioden 1984-1989 at en liten kollegagruppe gjennomførte en systematisk utdanning i psykoanalytisk orientert gruppeterapi ved hjelp av engelske læreterapeuter. Sammen grunnla de deretter en systematisk gruppeterapiutdanning i Norge og etablerte etter hvert Institutt for gruppeanalyse i 1992. En av pionerne i dette arbeidet var forfatteren av denne boken, og han har siden fortsatt sitt gruppeanalytiske engasjement både som terapeut $\mathrm{og}$ forsker.

Hovedinnholdet i denne velsignet kortfattede boken er såkalte kliniske retningslinjer for gjennomføring av langtids (to år) og korttids (seks måneder) analytisk gruppeterapi. Disse retningslinjene ble utarbeidet $i$ forbindelse med planleggingen og gjennomføringen av et omfattende forskningsprosjekt, hvor resultatene av disse to formene for gruppeterapi ble sammenliknet, og hvor det blant annet ble avklart hvilke pasienter som best profitterte på hvilken form for gruppeterapi.

Hensikten med retningslinjene er å sikre at terapeuter som vil gjennomføre analytisk gruppeterapi, vet hvordan dette skal gjøres og gjør det på samme måte, slik at kravene til evidensbasert medisin oppfylles. De tre hoveddelene heter Lang tids gruppeterapi, Kort tids gruppeterapi og Forskning. I begge terapidelene gjennomgås teori, metodologi, tekniske intervensjoner og kliniske eksempler på en klar, detaljert og meningsfull måte. Alle begreper, metoder og intervensjoner er definert, operasjonalisert og relatert til kliniske eksempler som gjenspeiler forfatterens omfattende kliniske erfaring. I siste del oppsummeres også noen av de interessante resultatene av det store forskningsprosjektet som forfatteren leder.

Boken er velegnet som lærebok for utdanningskandidater i gruppeanalyse, og for terapeuter som deltar i gruppeanalytisk forskning. For den som bare vil ha en kort, men presis beskrivelse av analytisk gruppeterapi, er dette et funn. Boken er utgitt på et velrennomert, internasjonalt forlag, noe som i seg selv er en fjær $\mathrm{i}$ hatten både for forfatteren og alle dem som har medvirket til å utvikle et gruppeanalytisk miljø i Norge.

Det er bare å gratulere med nok en viktig milepæl i arbeidet for å høyne kvaliteten av analytisk gruppeterapi.

Per Vaglum

Professor emeritus, Avdeling for medisinsk atferdsvitenskap Universitetet i Oslo 